\title{
PERATURAN PERPAJAKAN DAN DAMPAKNYA TERHADAP KEPATUHAN WAJIB PAJAK USAHA MIKRO KECIL MENENGAH
}

\author{
Andri Kamanjaya ${ }^{1}$, Joko Supriyanto ${ }^{2}$, Haqi Fadillah ${ }^{3}$ \\ 1, 2, 3 Universitas Pakuan, Bogor, Indonesia \\ Email korespondensi: ${ }^{2}$ abiyanto32@yahoo.com
}

\begin{abstract}
ABSTRAK
Penelitian ini bertujuan untuk menguji dan menganalisis Pengaruh Pemahaman PP No. 23 Tahun 2018 terhadap Kepatuhan Wajib Pajak usaha mikro kecil menengah (UMKM) dengan Pemahaman Insentif PPh Final UMKM Ditanggung Pemerintah sebagai Variabel Moderasi pada Wajib Pajak UMKM di Kota Bogor dan Kabupaten Bogor. Teknik pengambilan sampel yang digunakan dalam penelitian ini adalah purposive sampling. Metode analisis data menggunakan structural equation model (SEM). Hasil penelitian menunjukkan bahwa pemahaman terhadap PP No. 23 Tahun 2018 mempengaruhi tingkat kepatuhan wajib pajak UMKM. Sementara insentif yang diberikan pemerintah tidak mempengaruhi kepatuhan wajib pajak karena para wajib UMKM masih memiliki kendala dalam menerapkan insentif yang diberikan. Dengan demikian, diharapkan Direktorat Jenderal Pajak (DJP) dapat memberikan pembinaan berupa sosialisasi yang mudah diakses dan dimengerti oleh para wajib pajak UMKM mengenai pentingnya melaksanakan kewajiban perpajakan. Berdasarkan hasil analisis statistik deskriptif dan uji hipotesis dalam penelitian ini masih ditemukan cukup banyak wajib pajak UMKM yang belum memiliki NPWP dan masih kurangnya pemahaman terhadap insentif PPh UMKM ditanggung pemerintah.
\end{abstract}

Kata kunci: insentif pajak; kepatuhan wajib pajak; pemahaman pajak; usaha mikro kecil menengah

\section{ABSTRACT}

This study aims to examine and analyze the effect of understanding PP no. 23 of 2018 on Micro and Small Business Taxpayer Compliance with Understanding of MSME Final Income Tax Incentives Borne by the Government as Moderating Variables for MSME Taxpayers in Bogor City and Bogor Regency. The sampling technique used in this research is purposive sampling. The data analysis method uses a structural equation model (SEM). The results showed that the understanding of PP no. 23 of 2018 affects the level of compliance of MSME taxpayers. Meanwhile, incentives provided by the government do not affect taxpayer compliance because MSMEs are required to apply the incentives provided. Thus, it is hoped that the Directorate General of Taxes (DGT) can provide guidance in the form of socialization that is easily accessible and easily accessible by MSME taxpayers regarding the importance of implementing taxes. Based on descriptive statistical analysis and hypothesis testing in this study, it was found that quite a lot of MSME taxpayers did not have a TIN and there was still a lack of understanding of the MSME PPh incentives borne by the government.

Keywords: tax tax; taxpayer compliance; tax understanding; micro, small and medium enterprises

KETERANGAN ARTIKEL

Riwayat Artikel: diterima: 4 Oktober 2021; direvisi: 16 Desember 2021; disetujui: 24 Desember 2021

Klasifikasi JEL: H2O

Cara mensitasi: Kamanjaya, A., Supriyanto, J., \& Fadillah, H. (2021). Peraturan Perpajakan dan Dampaknya Terhadap Kepatuhan Wajib Pajak Usaha Mikro Kecil Menengah. JIAFE (Jurnal Ilmiah AKuntansi Fakultas Ekonomi), 7(2), 187-200. https://doi.org/10.34204/jiafe.v7i2.4010 
Andri Kamanjaya: Peraturan Perpajakan dan ...

\section{PENDAHULUAN}

Keberadaan Usaha Mikro, Kecil, dan Menengah (UMKM) mempunyai peranan yang cukup signifikan dalam perekonomian Indonesia. Dari 270,20 juta penduduk Indonesia pada tahun 2020 (Badan Pusat Statistik, 2020) jumlah UMKM di Indonesia bisa mencapai 64,2 juta pelaku usaha (Kementerian Koperasi dan UKM, 2018). Di sisi lain, jumlah UMKM yang terdaftar dalam sistem pajak terbilang minim, dengan angka sekitar 2,3 juta wajib pajak badan dan orang pribadi (Setiawan, 2020). Data ini menunjukan bahwa adanya kesenjangan atau gap antara tingkat penerimaan pajak oleh negara dengan jumlah UMKM yang tinggi.

Salah satu sumber penerimaan utama bagi negara yang diperlukan untuk membiayai pengeluaran negara ialah pajak. Kementerian Keuangan Republik Indonesia menyatakan bahwa Pajak Penghasilan (PPh) dan Pajak Pertambahan Nilai (PPN) menjadi sumber pemasukan utama dalam penerimaan pajak tahun 2019. Penerimaan pajak menyumbang Rp1,545.3 triliun dari Rp1,957.2 triliun realisasi pendapatan negara. Hal ini dapat disimpulkan bahwa potensi penerimaan pajak untuk negara sangat besar. Kepatuhan wajib pajak yang rendah ini disebabkan adanya peraturan yang dianggap terlalu memberatkan pembayar pajak. Mankiw (2011) menyatakan bahwa konsep tersebut tidak mencerminkan prinsip kemampuan membayar (ability-to-pay principle) dan terlihat seperti mengesampingkan aspek keadilan (equity principle). Ability-to-pay principle merupakan prinsip bahwa pajak seharusnya dipungut berdasarkan seberapa bisa orang itu bisa menanggung beban pajak.

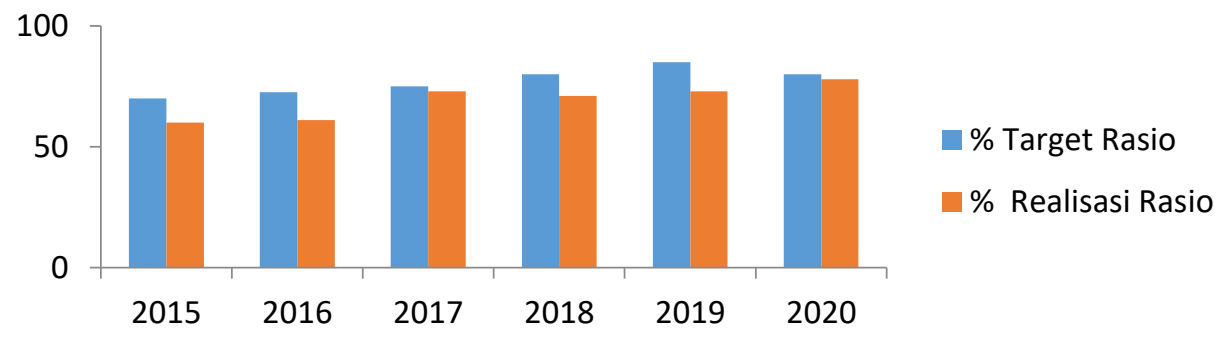

Sumber: Kementerian Keuangan Republik Indonesia, 2020

\section{Gambar 1. Rasio Kepatuhan Wajib Pajak}

Dari tahun ke tahun target rasio kepatuhan wajib pajak yang ditetapkan oleh pemerintah selalu lebih besar dibandingkan realisasi kepatuhan wajib pajak. Salah satu penyebabnya adalah pelaku UMKM di Indonesia yang masih belum banyak memahami pajak itu sendiri. Mayoritas pelaku UMKM memiliki kesulitan dalam hal laporan keuangan dan administrasi. Hal ini diakibatkan karena mereka tak memiliki sistem pembukuan yang komprehensif. Hal tersebut karena pengembangan UMKM yang dimulai dari usaha individu, lalu seiring waktu berkembang dan berbentuk badan dengan skala kecil dan menengah, sehingga pengetahuan mereka dibidang pembukuan dan perpajakan tidak memadai. Faktor tersebut yang menyebabkan kurangnya tingkat kepatuhan sector UMKM (Inasius, 2015).

Reformasi sektor perpajakan selalu dilakukan pemerintah meliputi perumusan dan penetapan peraturan perundang-undangan dan menyederhanakan administrasi perpajakan untuk memudahkan proses pelayanan bagi wajib pajak. Sampai tanggal 30 Juni 2018, PP No. 46 Tahun 2013 sudah tidak berlaku lagi dan digantikan oleh PP No. 23 Tahun 2018, mulai berlaku sejak 1 Juli 2018. Perubahan peraturan ini diharapkan mampu meningkatkan peran serta masyarakat dalam kegiatan ekonomi formal, lebih memberikan keadilan, dan memberikan kemudahan dalam melaksanakan kewajiban perpajakan, salah satu perubahan yang disorot adalah adanya perubahan tarif yang semula $1 \%$ berubah menjadi $0,5 \%$. 
Pengesahan peraturan terbaru ini memberikan langkah baik bagi pelaku UMKM. Beban pajak yang mereka harus bayar tidak sebesar berdasarkan peraturan sebelumnya, sehingga pelaku UMKM memiliki kapabilitas ekonomi yang lebih besar untuk memperluas kemampuan bisnisnya. Peraturan Pemerintah Nomor 23 Tahun 2018 merupakan usaha pemerintah untuk menghilangkan keluhan masyarakat akan peraturan sebelumnya. Peraturan atau regulasi dianggap bisa atau tidak bisa menjadi sebuah solusi karena tidak terlepas dari persepsi masyarakat, khususnya para wajib pajak atas peraturan tersebut. Di sisi lain, munculnya pandemi Covid-19 yang diduga muncul pada bulan desember 2019 dan berlangsung sampai saat ini mengakibatkan kemunduran yang besar di segala bidang, salah satunya pada bidang perekonomian. Demi mengatasi permasalahan ini, pemerintah melalui Direktorat Jenderal Pajak (DJP) melakukan penyesuaian melalui regulasi baru yaitu pemberian Insentif Pajak UMKM Ditanggung Pemerintah mulai bulan April sampai Desember 2020, sebelumya hanya berlaku sampai bulan september. Pada tahun 2021 pemerintah memperpanjang insentif pajak untuk meringankan wajib pajak menghadapi dampak Covid-19 hingga 30 Juni 2021, keputusan ini diatur dalam PMK No. 9/PMK.03/2021.

Terdapat beberapa penelitian yang pernah dilakukan mengenai penerapan PP No. 46 Tahun 2013 (berlaku sejak 1 Juli 2013 sampai dengan 30 Juni 2018) dan PP No. 23 tahun 2018 (berlaku sejak 1 Juli 2018) terhadap kepatuhan wajib pajak UMKM salah satunya penelitian yang dilakukan oleh Ma'rifah (2019) menyatakan bahwa pelaku UMKM menerima Peraturan Pemerintah No. 23 Tahun 2018. Hal ini dilihat dari responden UMKM yang dominan menjawab setuju dengan indikator pemahaman wajib pajak, dan sanksi pajak terhadap tingkat kepatuhan wajib pajak. Penelitian ini sepaham dengan penelitian yang dilakukan oleh Laksmi (2020) Hasil penelitian ini menunjukkan bahwa efektivitas sosialisasi perpajakan dan pengetahuan wajib pajak berpengaruh efektif untuk meningkatkan kepatuhan wajib pajak UMKM. Sosialisasi perpajakan UMKM yang dilaksanakan oleh KPP Pratama Malang Utara berpengaruh efektif untuk menambah pengetahuan wajib pajak terkait pajak UMKM. Pengetahuan wajib pajak yang diperoleh dari sosialisasi perpajakan dapat memberikan motivasi untuk patuh terhadap pajak. Kepatuhan wajib pajak ini dapat diketahui dari wajib pajak yang tepat waktu dalam menyampaikan SPT dan tidak memiliki tunggakan untuk semua jenis pajak.

Penelitian oleh Nurpratiwi dkk. (2014) menggunakan objek UMKM yang terdaftar di KPP Pratama Malang Utara, menunjukan bahwa persepsi wajib pajak ditinjau dari efektivitas pada perhitungan pajak yang terutang dan beban administrasi yang semakin berkurang adalah setuju, sedangkan pemahaman terhadap perundang-undangan dan keadilan tidak setuju PP No. 46 Tahun 2013 adalah tidak setuju. Namun, mengingat tidak sedikit wajib pajak UMKM yang belum memahami perpajakan secara menyeluruh dan tingkat kepatuhan wajib pajak UMKM yang layak untuk menerima insentif masih rendah dikhawatirkan pemberian insentif ini tidak berjalan secara maksimal.

Penelitian kembali perlu dilakukan untuk memahami apakah wajib pajak mengenal peraturan terbaru ini. Mengingat pemahaman itu bersifat subyektif terhadap suatu objek, peraturan baru ini tentunya akan menimbulkan pemahaman yang berbeda. Hal ini yang mendasari peneliti melakukan penelitian untuk melihat persepsi Kepatuhan Wajib Pajak pelaku UMKM dalam menyikapi Peraturan Pemerintah Nomor 23 Tahun 2018 dan Insentif Pajak UMKM Ditanggung Pemerintah. Berdasarkan permasalahan dalam penelitian, adapun tujuan yang ingin dicapai adalah: (1) menguji dan menganalisis pengaruh pemahaman PP No. 23 Tahun 2018 terhadap kepatuhan wajib pajak UMKM di Kota Bogor dan Kabupaten Bogor, (2) menguji dan menganalisis pemahaman Insentif PPh Final UMKM Ditanggung Pemerintah dapat memoderasi pengaruh pemahaman PP No. 23 tahun 2018 terhadap kepatuhan wajib pajak UMKM di Kota Bogor dan Kabupaten Bogor. 
Andri Kamanjaya: Peraturan Perpajakan dan ...

\section{KAJIAN LITERATUR \& PENGEMBANGAN HIPOTESIS Kepatuhan Wajib Pajak}

Menurut Juanda dkk. (2019) kepatuhan wajib pajak merupakan kepatuhan wajib pajak terhadap peraturan perpajakan dan indikatornya adalah ketertiban dan ketepatan dalam menghitung, membayar, dan melaporkan kewajiban pajak yang dilaporkan oleh Wajib Pajak. Menurut Nurmantu (2010) kepatuhan perpajakan merupakan kondisi ketika wajib pajak melakukan segala kewajiban perpajakannya dan melaksanakan hak perpajakannya. Kepatuhan perpajakan terdiri dari dua jenis yaitu: (1) kepatuhan formal yang merupakan suatu keadaan ketika wajib pajak memenuhi kewajiban perpajakan secara formal sesuai dengan ketentuan dalam Undang-Undang Perpajakan dan (2) kepatuhan material yang merupakan suatu keadaan di mana wajib pajak secara subtansi atau hakikat memenuhi semua aturan perpajakan, yakni sesuai dengan isi dan jiwa undang-undang perpajakan.

Wajib pajak harus memiliki rasa patuh untuk mengikuti peraturan perpajakan yang berlaku dan telah ditetapkan oleh Direktorat Jenderal Pajak, bahkan kepatuhan wajib pajak sendiri ditetapkan dalam Peraturan Menteri Keuangan Republik Indonesia Nomor 192/PMK.03/2007 Wajib Pajak dengan kriteria tertentu yang selanjutnya disebut sebagai Wajib Pajak Patuh adalah Wajib Pajak yang memenuhi persyaratan sebagai berikut tepat waktu dalam menyampaikan surat pemberitahuan, tidak mempunyai tunggakan pajak untuk semua jenis pajak, kecuali tunggakan pajak yang telah memperoleh izin mengangsur atau menunda pembayaran pajak, laporan keuangan diaudit oleh Akuntan Publik atau lembaga pengawasan keuangan pemerintah dengan pendapat wajar tanpa pengecualian (WTP) selama tiga tahun berturut-turut, dan tidak pernah dipidana karena melakukan tindak pidana dibidang perpajakan berdasarkan putusan pengadilan yang telah mempunyai kekuatan hukum tetap dalam jangka waktu lima tahun terakhir.

\section{Peraturan Pemerintah Nomor 23 Tahun 2018}

Peraturan Pemerintah Nomor 23 Tahun 2018 merupakan peraturan terbaru yang berisi tentang Pajak Penghasilan Atas Penghasilan dari Usaha yang Diterima Atau Diperoleh Wajib Pajak yang Memiliki Peredaran Bruto Tertentu, peraturan pemerintah ini menggantikan Peraturan Pemerintah Nomor 46 Tahun 2013. PP Nomor 23 Tahun 2018 yang terbit tanggal 8 Juni 2018 dan mulai diberlakukan tanggal 01 Juli 2018 telah menetapkan untuk mengurangi tarif PPh Final dari 1\% menjadi 0,5\%. Adapun salah satu tujuan peraturan ini adalah untuk memotivasi para pelaku UMKM semakin berkontribusi secara nyata dalam kegiatan ekonomi formal dengan adanya efektivitas dan efisiensi pembayaran pajak dan tarif yang lebih baik. Peraturan ini memaparkan bahwa penghasilan dari usaha yang diterima atau diperoleh wajib pajak dalam negeri yang memiliki peredaran bruto dengan jumlah tertentu.

Peraturan ini bersifat tidak wajib (bersifat pilihan) karena wajib pajak dapat menentukan sendiri untuk memilih tarif dengan skema PPh Final 0,500\%, atau menggunakan skema normal yang berdasarkan pada Undang-undang Nomor 36 Tahun 2008 Pasal 17 tentang Pajak Penghasilan. Sifat opsional ini memberi keuntungan bagi wajib pajak karena beberapa hal sebagai berikut. Bagi wajib pajak orang pribadi dan badan yang belum mampu mengupayakan pembukuan dengan tertib, penerapan PPh Final 0,500\% memberikan kemudahan bagi mereka untuk melaksanakan kewajiban perpajakan. Sebab, perhitungan pajak menjadi tidak sulit yakni 0,500\% dari peredaran bruto/omzet. Akan tetapi, pemanfaatan PPh Final mempunyai akibat yaitu WP tetap harus membayar pajak walaupun mengalami kerugian sama seperti peraturan sebelumnya (PP No. 46 Tahun 2013). Di sisi lain, WP badan yang telah melakukan pembukuan dengan benar dapat menempuh cara agar dikenai Pajak Penghasilan sesuai tarif normal yang ditetapkan di dalam pasal 17 UU No. 36 tahun 2008 tentang Pajak Penghasilan. Sebagai akibatnya, perhitungan tarif PPh akan berdasarkan pada lapisan penghasilan kena pajak. Di sisi lain, para wajib pajak tidak dikenai PPh bila mengalami kerugian fiskal. 


\section{Insentif Pajak Di Era Pandemi Covid-19}

Pemerintah melalui Direktorat Jenderal Pajak (DJP) telah mengeluarkan kebijakan dalam Perubahan atas PMK No. 86/PMK.03/2020 berupa pemberian insentif PPh UMKM Ditanggung Pemerintah (DTP) dari masa pajak april 2020 sampai bulan desember 2020 bagi Wajib Pajak yang memiliki peredaran bruto tertentu berdasarkan PP No. 23 tahun 2018. Berdasarkan laporan DJP per 10 September 2020, baru 218.000 wajib pajak UMKM yang telah menggunakan insentif PPh Final. Pada tahun 2021 pemerintah memperpanjang insentif pajak untuk membantu wajib pajak menghadapi dampak Covid- 19 hingga 30 Juni 2021, keputusan ini diatur dalam PMK No. 9/PMK.03/2021.

Salah satu alasan yang melatarbelakangi pemberian insentif bagi UMKM karena masyarakat yang menjalankan UMKM kehilangan sumber penghasilan. UMKM tidak mempunyai kemampuan untuk membayar hak upah pekerja, bahkan pada kasus terburuk pemutusan hubungan kerja bisa terjadi secara sepihak (Sugiri, 2020). Marlinah (2020) menyebutkan bahwa pemberian insentif ini dapat mengurangi beban usaha yang UMKM keluarkan, sehingga UMKM mampu untuk bertahan. Wajib pajak UMKM bisa mendapatkan insentif ini dengan cara menyampaikan laporan realisasi PPh Final DTP di situs www.pajak.go.id paling lambat tanggal 20 bulan berikutnya. Wajib Pajak UMKM tidak perlu lagi menyetor pajak dan dipotong/ dipungut lagi oleh pemotong/ pemungut pajak. Pemerintah berharap agar uang yang seharusnya wajib pajak UMKM setorkan untuk diputarkan kembali di dalam usahanya.

\section{Pengaruh Pemahaman PP No. 23 Tahun 2018 terhadap Kepatuhan Wajib Pajak UMKM}

Peraturan Pemerintah Nomor 23 Tahun 2018 adalah pengganti Peraturan Pemerintah Nomor 46 Tahun 2013 Tentang Pajak Penghasilan Atas Penghasilan Dari Usaha Yang Diterima Atau Diperoleh Wajib Pajak Yang Memiliki Peredaran Bruto Tertentu. PP Nomor 23 tahun 2018 diterbitkan pada tanggal 08 Juni 2018 dan mulai diberlakukan tanggal 01 Juli 2018. Adapun salah satu tujuan peraturan ini adalah untuk mengajak pelaku UMKM agar semakin berperan aktif pada kegiatan ekonomi formal dengan kemudahan pembayaran pajak dan tarif yang lebih baik. Penelitian terdahulu yang dilakukan oleh Mayangsari (2019) menunjukkan bahwa jumlah Wajib Pajak UMKM mengalami peningkatan setelah diberlakukannya PP No. 23 Tahun 2018. Hasil penelitian yang dilakukan oleh Ma'rifah (2019) menunjukkan bahwa pelaku UMKM menerima Peraturan Pemerintah No. 23 Tahun 2018.

$\mathrm{H}_{1}$ : pemahaman PP No. 23 Tahun 2018 berpengaruh positif terhadap kepatuhan wajib pajak UMKM.

Pengaruh Pemahaman Insentif PPh Final DTP dalam Memoderasi Pengaruh Pemahaman PP No. 23 Tahun 2018 terhadap Kepatuhan Wajib Pajak UMKM

Pandemi virus Covid-19 telah menimbulkan dampak penurunan ekonomi disegala bidang terutama pada sektor UMKM. Pemerintah melalui Direktorat Jenderal Pajak (DJP) melakukan penyesuaian melalui bermacam regulasi yaitu pemberian Insentif Pajak UMKM Ditanggung Pemerintah. Regulasi yang terbaru, PMK No. 9/PMK.03/2021 menetapkan bahwa pemberian insentif diperpanjang sampai 30 Juni 2021. Pemberian insentif ini diharapkan agar para pelaku UMKM mampu mempertahankan usahanya selama masa pandemi. Insentif pajak penghasilan (PPh) Final ditujukan kepada para wajib pajak yang mempunyai peredaran bruto tertentu sesuai dengan ketentuan yang diatur dalam Peraturan Pemerintah Nomor 23 Tahun 2018 yang dikenai PPh Final sebesar 0,5\% (nol koma lima persen) dari jumlah peredaran bruto. Penelitian yang dilakukan oleh Mudiarti \& Mulyani (2020) menyimpulkan bahwa Wajib Pajak UMKM yang berada di kota Kudus memiliki kemauan menjalankan kewajiban perpajakan berpengaruh signifikan seiring dengan tingginya pemahaman akan kebijakan pemberian 
insentif PPh Final DTP. Hasil penelitian Susyanti \& Anwar (2020) menunjukkan bahwa UMKM masih bingung dalam menerapkan insentif perpajakan UMKM pada saat pandemi Covid-19.

$\mathrm{H}_{2}$ : pemahaman insentif pph final dtp dapat memoderasi pengaruh pemahaman PP No. 23 Tahun 2018 terhadap kepatuhan wajib pajak UMKM.

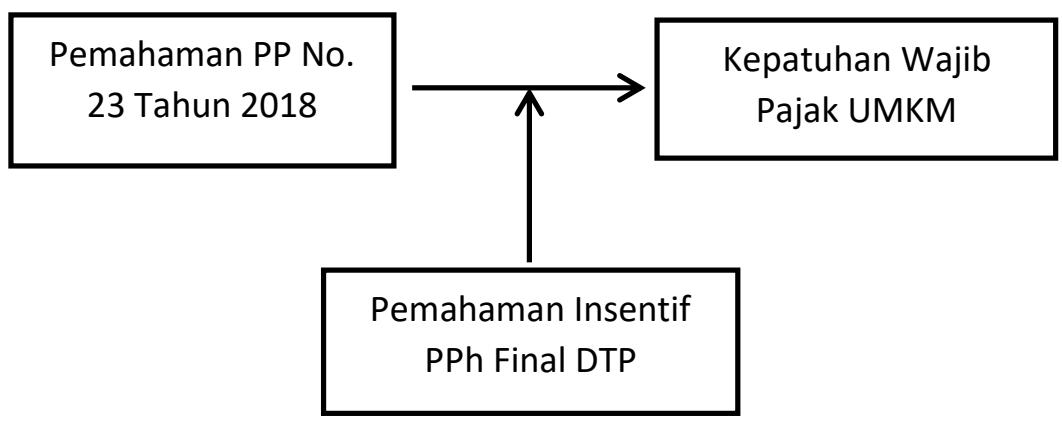

Gambar 2. Kerangka Konseptual

\section{METODE PENELITIAN}

Penelitian ini adalah penelitian verifikatif dengan metode penelitian explanatory survey mengenai pengaruh pemahaman PP No. 23 Tahun 2018 terhadap kepatuhan wajib pajak UMKM dengan Pemahaman Insentif PPh Final UMKM ditanggung pemerintah sebagai variabel moderasi pada wajib pajak UMKM di Kota Bogor dan Kabupaten Bogor. Penelitian ini juga dikategorikan sebagai penelitian deskriptif survei. Metode deskriptif survei adalah metode yang bertujuan untuk mengambil sampel dari suatu populasi dan menggunakan kuesioner sebagai alat pengumpulan data.

Jenis data penelitian ini adalah data primer yang dikumpulkan melalui penyebaran kuesioner kepada wajib pajak UMKM yang menjalankan usaha di daerah Kota Bogor dan Kabupaten Bogor. Pengambilan sampel menggunakan teknik purposive sampling yaitu teknik penentuan sampel di mana semua individu dalam populasi yaitu para wajib pajak UMKM di Kota Bogor dan Kabupaten Bogor dipilih sesuai kriteria yang sudah ditentukan. Kriteria yang digunakan yaitu wajib pajak UMKM yang: (1) berdomisili dan memiliki usaha di Kota Bogor dan Kabupaten Bogor, (2) mempertimbangkan untuk memakai fasilitas Insentif PPh Final UMKM ditanggung Pemerintah, (3) hanya bekerja di rumah (work from home) selama pandemi COVID-19, (4) mampu menggunakan dan mengisi kuesioner melalui google form , dan (5) bersedia untuk berpartisipasi menjadi responden.

Skala pengukuran yang digunakan dalam penelitian ini adalah skala likert, dengan data ordinal pengukuran data menggunakan skala likert dari poin 1 sampai dengan 5 , yang ukurannya sangat tidak setuju, tidak setuju, ragu-ragu, setuju dan sangat setuju. Metode analisis data menggunakan analisis statistik deskriptif dan partial least square yang terdiri dari outer model dan inner model. Outer model digunakan untuk menilai validitas dan reliabilitas model. Inner model digunakan untuk memprediksi hubungan kausalitas antar variabel laten. outer model terdiri dari tiga komponen yang terdiri dari (1) convergent validity, (2) discriminant validity, (3) composite reliability. Sedangkan untuk menguji evaluasi model struktural (inner model) digunakan nilai $r$-square, dan untuk melihat nilai signifikansi untuk mengetahui pengaruh antar variabel dilakukan prosedur bootstrapping dalam program SmartPLS.

\section{HASIL DAN PEMBAHASAN}

Data untuk penelitian ini diperoleh dengan menggunakan kuesioner dengan media Google Form. Dari 100 kuesioner yang disebar, seluruhnya telah kembali dan dapat diolah. Tabel berikut ini menunjukkan 
deskripsi mengenai ciri 100 responden menurut jenis kelamin, usia, pendidikan terakhir, jenis usaha, kepemilikan NPWP, lokasi usaha, dan lama usaha.

Tabel 1. Deskripsi Responden

\begin{tabular}{|c|c|c|}
\hline $\begin{array}{l}\text { Karakteristik } \\
\text { Responden }\end{array}$ & Jumlah (Responden) & Persentase (\%) \\
\hline \multicolumn{3}{|l|}{ Jenis Kelamin: } \\
\hline Laki-laki & 59 & 59 \\
\hline Perempuan & 41 & 41 \\
\hline \multicolumn{3}{|l|}{ Usia (tahun): } \\
\hline$<30$ & 78 & 78 \\
\hline $31-40$ & 8 & 8 \\
\hline $41-50$ & 10 & 10 \\
\hline $51-60$ & 4 & 4 \\
\hline$>60$ & 0 & 0 \\
\hline \multicolumn{3}{|l|}{ Tingkat Pendidikan: } \\
\hline SMP & 10 & 10 \\
\hline SMA & 74 & 74 \\
\hline Akademi (DIII) & 1 & 1 \\
\hline Strata satu (S1) & 13 & 13 \\
\hline Strata dua (S2) & 1 & 1 \\
\hline Lain-lain & 1 & 1 \\
\hline \multicolumn{3}{|l|}{ Jenis Usaha: } \\
\hline Usaha pribadi & 94 & 94 \\
\hline $\begin{array}{l}\text { Badan usaha (CV, } \\
\text { firma, dll) }\end{array}$ & 6 & 6 \\
\hline \multicolumn{3}{|l|}{ Kepemilikan NPWP: } \\
\hline Punya NPWP & 14 & 14 \\
\hline Tidak punya NPWP & 86 & 86 \\
\hline \multicolumn{3}{|l|}{ Lokasi Usaha: } \\
\hline Kota Bogor & 43 & 43 \\
\hline Kabupaten Bogor & 57 & 57 \\
\hline \multicolumn{3}{|l|}{ Lama Usaha: } \\
\hline$\leq 1$ tahun & 25 & 25 \\
\hline$>1$ tahun -5 tahun & 51 & 51 \\
\hline$>5$ tahun & 24 & 24 \\
\hline
\end{tabular}

Berdasarkan statistik deskriptif responden penelitian disimpulkan bahwa pelaku UMKM sebagian besar adalah laki-laki dengan usia di bawah 30 tahun dengan rata-rata merupakan tamatan sekolah menengah atas. Hal ini menunjukkan bahwa para pelaku usaha masih pada usia yang produktif dan masih mampu mengakses informasi lebih banyak dan cepat. Hampir sebagian besar jenis usaha adalah usaha pribadi dimana pada umumnya usaha yang dimiliki secara perseorangan dianggap belum memiliki kewajiban hukum termasuk terkait perpajakan. Hal ini dibuktikan dengan sebesar $86 \%$ dari 
responden tidak memiliki NPWP yang menunjukkan rendahnya kesadaran pelaku UMKM akan kewajiban perpajakannya.

\section{Pengujian Structural Equation Model (SEM)}

Metode analisis utama yang digunakan dalam penelitian ini yaitu dengan Structural Equation Model (SEM). Pengujian dilakukan dengan bantuan software SmartPLS 3.0. Loading factor adalah ukuran korelasi antara indikator dengan variabel latennya. Variabel laten yaitu variabel yang tidak terukur secara langsung dan membutuhkan beberapa indikator. Variabel laten dalam penelitian ini terdiri dari tiga variabel yaitu kepatuhan wajib pajak UMKM (variabel Y), pemahaman PP No. 23 Tahun 2018 (variabel X), dan pemahaman insentif PPh Final UMKM ditanggung pemerintah (variabel M). Standar yang digunakan dalam loading factor convergent validity diharapkan $>0,5$, namun nilai yang lebih baik diharapkan $>0,7$. Di dalam penelitian ini nilai loading factor kurang dari 0,7 di-drop (dikeluarkan) agar bisa memenuhi syarat discriminant validity.

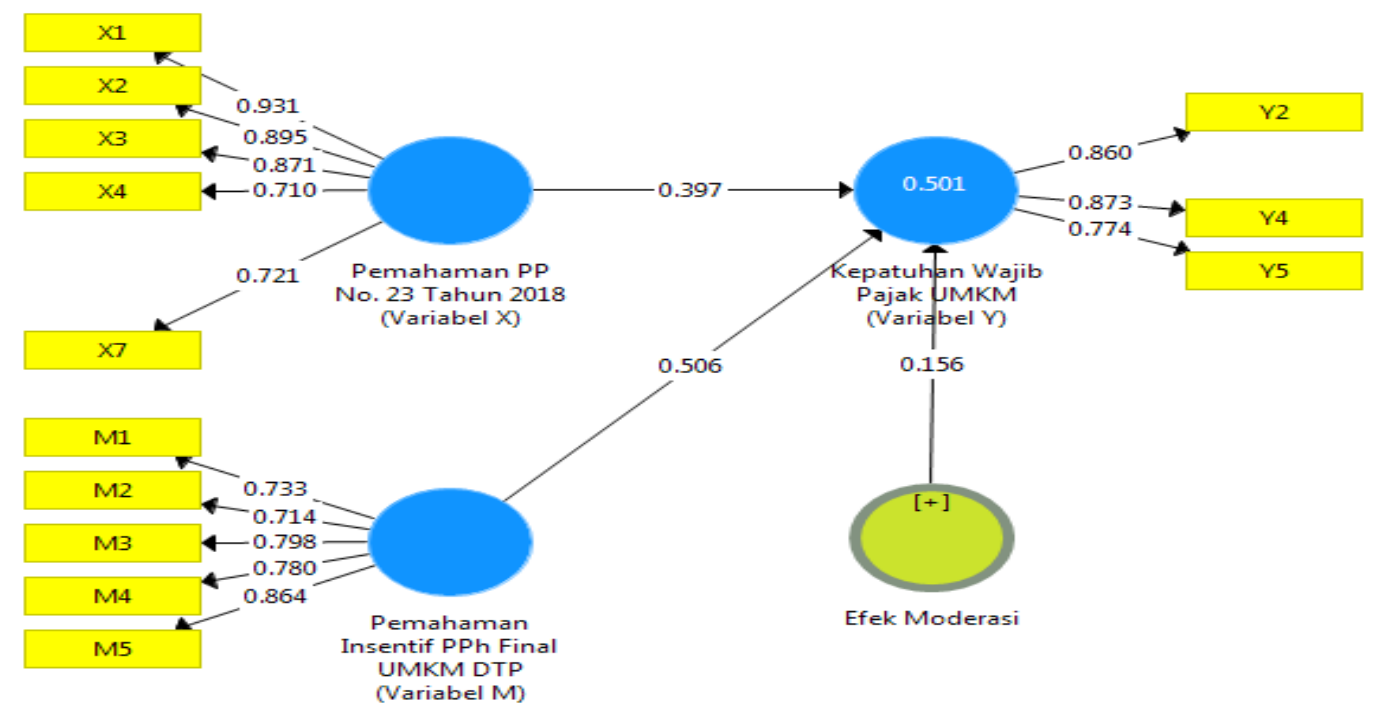

\section{Gambar 3. Uji Full Model SEM Setelah Drop Indikator}

\section{Uji Outer Model-Convergen Validity}

Nilai convergent validity bertujuan menguji validitas dari masing-masing indikator variabel dependen dan independen. Indikator dikatakan valid jika nilai loading factor di atas 0,700 . Berikut adalah hasil uji convergen validity. 
Tabel 2. Hasil Uji Convergent Validity

\begin{tabular}{lccc}
\hline \multicolumn{1}{c}{ Variabel } & & Loading Factor & Keterangan \\
\hline Kepatuhan Wajib & Y2 & 0,860 & Valid \\
Pajak UMKM & Y4 & 0,873 & Valid \\
& Y5 & 0,774 & Valid \\
Pemahaman PP No. 23 & X1 & 0,931 & Valid \\
Tahun 2018 & X2 & 0,895 & Valid \\
& X3 & 0,871 & Valid \\
& X4 & 0,710 & Valid \\
Pemahaman Insentif & X7 & 0,721 & Valid \\
PPh Final UMKM DTP & M2 & 0,733 & Valid \\
& M3 & 0,714 & Valid \\
& M4 & 0,798 & Valid \\
& M5 & 0,780 & Valid \\
& & & Valid \\
\hline
\end{tabular}

Tabel 2 menunjukkan bahwa seluruh indikator variabel dependen dan independen memiliki loading faktor $>0,700$ yang berarti bahwa semua indikator konstruk adalah valid. Hal ini menunjukkan bahwa seluruh indikator valid untuk mengukur konstruk variabel kepatuhan wajib pajak, pemahaman PP No. 23 Tahun 2018, dan pemahaman insentif PPh Final.

\section{Uji Hipotesis}

Pengujian hipotesis yang diusulkan ditempuh dengan cara melakukan pengujian pada model struktural (inner model) dengan melihat path coefficients yang menampilkan koefisien parameter dan nilai signifikansi t statistik. Signifikansi parameter yang diestimasi dapat memberikan informasi mengenai hubungan antar variabel yang digunakan dalam penelitian. Batas untuk menolak dan menerima hipotesis yang diajukan di atas adalah sig $\mathrm{P}$ values $<0,050$.

Tabel 3. Uji Hipotesis berdasarkan Path Coefficient

\begin{tabular}{lcc}
\hline & Original Sample (0) & P Values \\
\hline $\begin{array}{l}\text { Pemahaman PP No. 23 Tahun 2018 } \\
\text { Kepatuhan Wajib Pajak UMKM }\end{array}$ & 0,397 & 0,032 \\
\hline
\end{tabular}

Hipotesis pertama menyatakan terdapat pengaruh positif antara pemahaman PP No. 23 Tahun 2018 terhadap kepatuhan wajib pajak UMKM. Tabel 3 menunjukkan bahwa variabel pemahaman PP No. 23 Tahun 2018 mempunyai tingkatan signifikan sebesar 0,032 yaitu lebih kecil dari 0,05 dan nilai $\mathrm{t}$ tabel $<\mathrm{t}$ hitung $(1,660<2,151)$. Nilai koefisien parameternya sebesar 0,397 . Hal ini menunjukkan semakin baik pemahaman PP No. 23 Tahun 2018 maka kepatuhan wajib pajak UMKM akan semakin meningkat. Hal ini berarti $\mathrm{H}_{1}$ diterima sehingga bisa disimpulkan bahwa pemahaman PP No. 23 Tahun 2018 berpengaruh positif terhadap kepatuhan wajib pajak UMKM. 
Andri Kamanjaya: Peraturan Perpajakan dan ...

Tabel 4. Uji Hipotesis berdasarkan Efek Moderasi

\begin{tabular}{lccc}
\hline & & Original Sample (O) & P Values \\
\hline $\begin{array}{l}\text { Efek Moderasi } \\
\text { Pajak UMKM }\end{array}$ & & 0,156 & 0,279 \\
\hline
\end{tabular}

Hipotesis kedua menyatakan tidak terdapat pengaruh positif antara pemahaman PP No. 23 Tahun 2018 terhadap kepatuhan wajib pajak UMKM dengan di moderasi oleh pemahaman insentif PPh Final UMKM ditanggung pemerintah. Tabel 4.19 menunjukkan bahwa variabel pemahaman PP No. 23 Tahun 2018 memiliki tingkat signifikan sebesar 0,279 yaitu lebih besar dari 0,050 dan nilai $t$ tabel $>t$ hitung $(1,660>1,084)$. Nilai koefisien parameternya sebesar 0,156 . Hal ini menunjukkan bahwa $\mathrm{H}_{2}$ ditolak dan berarti pemahaman insentif PPh Final ditanggung pemerintah tidak dapat memoderasi pengaruh pemahaman PP No. 23 Tahun 2018 terhadap Kepatuhan Wajib Pajak UMKM.

\section{Pengaruh Pemahaman PP No. 23 Tahun 2018 terhadap Kepatuhan Wajib Pajak UMKM}

Salah satu alasan mengapa pemerintah mengeluarkan PP No. 23 Tahun 2028 adalah demi memotivasi para pelaku UMKM agar mampu merasakan kemudahan dalam pembayaran pajak dengan tarif yang lebih baik. Kemudahan yang diberikan diantaranya yaitu jangka waktu pengenaan dalam penerapan bagi wajib pajak perseroan terbatas (PT) yaitu tiga tahun; CV, firma, dan koperasi yaitu empat tahun; dan bagi wajib pajak orang pribadi yaitu tujuh tahun, serta adanya tarif yang dikenakan yaitu sebesar $0,5 \%$ dari seluruh peredaran bruto.

Hasil penelitian menunjukkan bahwa pemahaman PP No. 23 Tahun 2018 berpengaruh positif terhadap kepatuhan wajib pajak UMKM. Semakin baik pemahaman wajib pajak pelaku UMKM terhadap PP No. 23 Tahun 2018, maka tingkat kepatuhan wajib pajak akan semakin meningkat. Indikator yang membentuk pemahaman PP No. 23 Tahun 2018 yaitu: (1) PP No. 23 Tahun 2018 tentang Pajak Penghasilan Final dikhususkan untuk pengusaha dengan peredaran bruto Peredaran bruto $\leq \mathrm{Rp} 4,8 \mathrm{M}$; (2) PP No. 23 Tahun 2018 adalah pajak penghasilan yang bersifat final, (3) Tarif pajak 0,5\% dari total omzet satu tahun; (4) Adanya sanksi perpajakan, (5.) Sanksi pajak diperlukan untuk mendisiplinkan WP, (6) Sanksi administrasi perpajakan; dan (7) Sanksi pidana perpajakan. Wajib pajak yang mengerti dan menerapkan isi pada undang-undang dan ketentuan perpajakan, serta mengetahui adanya sanksi pajak, akan menghitung, membayar serta melaporkan pajaknya dengan sukarela, benar, dan tepat waktu. Hal ini dikarenakan wajib pajak memahami pajak yang disetorkannya dimanfaatkan untuk pembangunan negara dan fasilitas umum yang berguna untuk kepentingan masyarakat.

Hasil penelitian ini sejalan dengan self assessment system yang Resmi (2019) kemukakan, yaitu adanya inisiatif oleh wajib pajak untuk menghitung, membayar, melaporkan, dan mempertanggungjawabkan pajak yang terutang sendiri. Hasil penelitian ini juga sejalan dengan yang dilakukan oleh Mohdali dkk. (2014) yang menyimpulkan bahwa pemberian rasa takut dalam bentuk sanksi perpajakan bertujuan agar wajib pajak mau memenuhi kewajiban perpajakannya. Ma'rifah (2019) dalam penelitiannya juga menyimpulkan bahwa pelaku UMKM menerima Peraturan Pemerintah No. 23 Tahun 2018.

Pengaruh Pemahaman Insentif PPh Final DTP dalam Memoderasi Pengaruh Pemahaman PP No. 23 Tahun 2018 terhadap Kepatuhan Wajib Pajak UMKM

Kebijakan yang dikeluarkan pemerintah demi membantu wajib pajak UMKM yang terdampak pandemi yaitu berupa insentif PPh UMKM Ditanggung Pemerintah dari April 2020 sampai Desember 2020. Pemerintah berharap program ini agar berjalan dengan efektif agar para wajib pajak UMKM mampu mempertahankan usahanya di tengah pandemi serta menjaga agar perekonomian Indonesia tetap 
berjalan dengan stabil, karena UMKM merupakan unit usaha terbesar di Indonesia (Kementerian Koperasi dan UKM Republik Indonesia, 2020).

Hasil penelitian menunjukkan bahwa pemahaman insentif PPh Final UMKM ditanggung pemerintah tidak dapat memoderasi pengaruh pemahaman PP No. 23 Tahun 2018 terhadap kepatuhan wajib pajak UMKM. Pemahaman PP No. 23 Tahun 2018 yang dimoderasi oleh pemahaman insentif PPh Final ditanggung pemerintah tidak dapat memperkuat kepatuhan wajib pajak UMKM secara langsung. $\mathrm{Hal}$ ini dapat disebabkan karena wajib pajak yang mengajukan diri untuk mendapatkan fasilitas tidak mengetahui adanya kewajiban untuk melakukan pelaporan dan wajib pajak tidak mengetahui bagaimana cara menerapkan realisasi insentif pajak yang dilakukan secara online (daring). Oleh karena itu, Direktorat Jenderal Pajak (DJP) harus meningkatkan pengetahuan dan mendorong sikap wajib pajak UMKM diantaranya melalui sosialisasi perpajakan kepada masyarakat. Penelitian ini sejalan dengan penelitian yang dilakukan oleh Faradisty dan Sisniarti (2020) bahwa sebagian wajib pajak pelaku UMKM tidak mengetahui seperti apa penerapan dari intensif pajak tersebut. Hasil penelitian Susyanti \& Anwar (2020) juga menunjukkan bahwa masih banyak pelaku UMKM yang masih belum mengerti dalam menerapkan peraturan perpajakan.

\section{KESIMPULAN}

Pemahaman PP No. 23 Tahun 2018 berpengaruh positif terhadap kepatuhan wajib pajak UMKM. Semakin baik pemahaman wajib pajak pelaku UMKM terhadap PP No. 23 Tahun 2018, maka tingkat kepatuhan wajib pajak akan semakin meningkat. Hal ini sesuai dengan pertanyaan pada kuesioner yang menyatakan wajib pajak UMKM memiliki pemahaman terhadap ketentuan perpajakan serta Peraturan Pemerintah (PP) No. 23 tahun 2018 dan bagi wajib pajak yang terlambat atau tidak membayar pajak dapat diberikan sanksi administrasi dan sanksi pidana sehingga wajib pajak akan semakin patuh menjalankan kewajiban perpajakannya. Pemahaman insentif PPh Final UMKM ditanggung pemerintah tidak dapat memoderasi pengaruh pemahaman PP No. 23 Tahun 2018 terhadap kepatuhan wajib pajak UMKM. Pemahaman PP No. 23 Tahun 2018 yang dimoderasi oleh pemahaman insentif PPh Final UMKM ditanggung pemerintah tidak dapat memperkuat kepatuhan wajib pajak UMKM secara langsung. Hal ini dapat disebabkan karena kurangnya pemahaman insentif PPh Final UMKM ditanggung pemerintah oleh para wajib pajak pelaku UMKM. Hal lainnya disebabkan oleh wajib pajak yang mendaftar untuk mendapatkan fasilitas tidak tahu adanya kewajiban untuk melakukan pelaporan dan wajib pajak tidak tahu bagaimana cara melakukan realisasi insentif pajak yang dilakukan secara online (daring). Berdasarkan hasil penelitian, diharapkan Direktorat Jenderal Pajak (DJP) dapat memberikan pembinaan berupa sosialisasi yang mudah diakses dan dimengerti oleh para wajib pajak UMKM mengenai pentingnya melaksanakan kewajiban perpajakan. Karena berdasarkan hasil analisis statistik deskriptif dan uji hipotesis dalam penelitian ini masih ditemukan cukup banyak wajib pajak UMKM yang belum memiliki NPWP dan masih kurangnya pemahaman terhadap insentif PPh UMKM ditanggung pemerintah.

\section{DAFTAR PUSTAKA}

Badan Pusat Statistik. (2021). Hasil Sensus Penduduk 2020. https://www.bps.go.id/pressrelease/2021/01/21/1854/hasil-sensus-penduduk-2020.html

Faradisty, A. \& Sisniarti. (2020). Strategi Bisnis dan Pemanfaatan Insentif Pajak di Masa Pandemi COVID19 dan Era New Normal (Studi Kasus Pelaku UKM Onlineshop di Media Sosial dan Marketplace di Pekanbaru). The Journal of Tax Centre, 1(2), 174-189. http://dx.doi.org/10.24014/jot.v1i2.12261 
Andri Kamanjaya: Peraturan Perpajakan dan ...

Inasius, F. (2015). Pajak Penghasilan Orang Pribadi Usaha Mikro dan Kecil di Indonesia: Kebijakan dan Implikasi. BINUS Business Review, 6(1), 1-10.

Juanda, A., dkk. (2019). Membangun Ekonomi Nasional yang Kokoh. Malang: Universitas Muhammadiyah Malang.

Kementrian Keuangan Republik Indonesia. (2007). Peraturan Menteri Keuangan Republik Indonesia Nomor 192/PMK.03/2007 Tentang Tata Cara Penetapan Wajib Pajak dengan Kriteria Tertentu Dalam Rangka Pengembalian Pendahuluan Kelebihan Pembayaran Pajak. Lembaran Negara Republik Indonesia Tahun 2007. https://jdih.kemenkeu.go.id/fulltext/2007/192 pmk.03 2007per.htm

(2020). APBN Kita Kinerja dan Fakta Edisi Desember 2020. https://www.kemenkeu.go.id/publikasi/apbn-kita/

. (2021). Peraturan Menteri Keuangan Republik Indonesia Nomor 9 Tahun 2021 Tentang Insentif Pajak untuk Wajib Pajak Terdampak Pandemi Corona Virus Disease 2019. https://www.kemenkeu.go.id/media/18031/pmk-9-tahun-2021.pdf

Kementerian Koperasi dan UKM Republik Indonesia. (2018). Perkembangan Data Usaha Mikro, Kecil, Menengah (UMKM) dan Usaha Besar (UB) Edisi 3. https://www.kemenkopukm.go.id/uploads/laporan/1584006686_UMKM\%2020162017\%20rev.pdf

. (2020). Petugas Penyuluh Koperasi Lapangan Kementrian Koperasi dan UKM Republik Indonesia. https://ppkl.kemenkopukm.go.id

Laksmi, E. W. P. (2020). Analisis Efektivitas Sosialisasi Perpajakan dan Pengetahuan Wajib Pajak dalam Rangka Meningkatkan Kepatuhan Wajib Pajak Usaha Mikro Kecil dan Menengah (UMKM) (Studi Pada KPP Pratama Malang Utara). Universitas Islam Negeri Maulana Malik Ibrahim Malang.

Mankiw, N. G. (2011). Principles of Economics 6th Edition. Boston: South-Western Cengage Learning.

Ma'rifah, A. U. (2019). Analisis Pemberlakuan Pajak UMKM Terhadap Tingkat Kepatuhan Wajib Pajak UMKM. Universitas Bhayangkara Surabaya.

Marlinah, L. (2020). Peluang dan Tantangan UMKM Dalam Upaya Memperkuat Perekonomian Nasional Tahun 2020 Ditengah Pandemi Covid 19. Jurnal Ekonomi, 22(2), 118-124. https://doi.org/10.37721/je.v22i2.644

Mayangsari, N. (2019). Evaluasi Penerapan PP No. 23 Tahun 2018 Tentang Penerimaan PPh Wajib Pajak UMKM (Studi Pada Kantor Pelayanan Pajak Pratama Kendari). Universitas Haluoleo.

Mohdali, R. Isa, K., \& Yusoff, S, H. (2014). The Impact of Threat Of Punishment On Tax Compliance And Non Compliance Attitudes in Malaysia. Social and Behavioral Sciences, 164, 291-297. http://dx.doi.org/10.1016/j.sbspro.2014.11.079

Mudiarti, H., \& Mulyani, U. R. (2020). Pengaruh Sosialisasi dan Pemahaman Peraturan Menteri Keuangan Nomor 86 Tahun 2020 terhadap Kemauan Menjalankan Kewajiban Perpajakan Pada Masa Covid-19 (Pada UMKM Orang Pribadi Sektor Perdagangan di Kudus). Accounting Global Journal, 4(2), 167-182.

Nurmantu, S. (2005). Pengantar Perpajakan Edisi Ketiga. Jakarta: Granit.

Nurpratiwi, A., et al. (2014). Analisis Persepsi Wajib Pajak Pemilik UMKM Terhadap Penetapan Kebijakan Pajak Penghasilan Final Sesuai Peraturan Pemerintah No. 46 Tahun 2013 (Studi Pada KPP Pratama Malang Utara). Jurnal Mahasiswa Perpajakan, 2(1), 1-6.

Republik Indonesia. (2018). Peraturan Pemerintah Republik Indonesia Nomor 23 Tahun 2018 tentang Pajak Penghasilan Atas Penghasilan Dari Usaha yang Diterima Atau Diperoleh Wajib Pajak yang Memiliki Peredaran Bruto Tertentu. https://www.pajak.go.id/sites/default/files/201905/PP\%20Nomor\%2023\%20Tahun\%202018.pdf

Resmi, S. (2019). Perpajakan: Teori dan Kasus Edisi ke-11. Jakarta: Salemba Empat. 
JIAFE (Jurnal Ilmiah Akuntansi Fakultas Ekonomi)

Vol.7 No.2, Des 2021, Hal. 187-200

https://journal.unpak.ac.id/index.php/jiafe P-ISSN: 2502-3020, E-ISSN: 2502-4159

Setiawan, D.A. (2020). Dinilai Tahan Banting, Kontribusi UMKM Ke Pajak Diharapkan Naik. DDTC News. https://news.ddtc.co.id/dinilai-tahan-banting-kontribusi-umkm-ke-pajak-diharapkan-naik-19020

Sugiri, D. (2020). Menyelamatkan Usaha Mikro, Kecil dan Menengah dari Dampak Pandemi Covid-19. Fokbis: Media Pengkajian Manajemen dan Akuntansi, 19(1), 76-86. https://doi.org/10.32639/fokusbisnis.v19i1.575

Susyanti, J., \& Anwar, S. A. (2020). Efek Sikap Wajib Pajak, Kesadaran Wajib Pajak, Pengetahuan Perpajakan terhadap Kepatuhan Pajak di Masa Covid-19. Sebatik: Sekolah Tinggi IImu Informatika dan Komputer, 24(2), 171-177. 
